\title{
Geopolitical Perspective, in The Relations of the U.S. And Iraqi Kurdistan Region Since 2003.
}

\section{Arez Abdulqader Abdullah}

Employee at Ministry of Culture and Youth in Kurdistan Regional Government, Erbil, Iraq. Lecturer in Department of International Relations and Diplomacy, College of Law and International Relations, Bayan University, Erbil, Kurdistan Region, Iraq.

arez.qadir83@gmail.com

\section{ARTICLE INFO}

\section{Article History:}

Received: $1 / 4 / 2021$

Accepted: $11 / 5 / 2021$

Published: Spring 2021

\section{Keywords:}

Geopolitical perspective; The United State; The Iraqi Kurdistan Region; The Iraq war (2003); The Islamic State since 2014; Security and Stability.

Doi:

10.25212/Ifu.qzj.6.2.36

\section{ABSTRACT}

This article focuses on the geopolitical perspective, in the relations between America and Iraqi Kurdistan Region since 2003. Since then, the Iraqi Kurdistan Region has become a good ally of the U.S. because the region geopolitically is significant for the United State foreign policy. The Iraqi Kurdistan Region has been using its strategic location in order to enhance its relations with the U.S. The purpose of the study is to explore the significance of geopolitical perspective in the U.S. and KRI relations since 2003. This paper examines that by focusing on two main factors. Firstly, the military relations between the U.S. and the IKR, which are the Iraq war in 2003 and the Islamic State war since 2014. Secondly, security and stability of the Iraqi Kurdistan Region. This research aims to answer the main question: dose geopolitical perspective influence on relations between the U.S. and the Iraqi Kurdistan Region? This research concludes that for the US the geopolitical of KRI is significant. Ultimately, it appears that there is a good relationship between the U.S. and the Iraqi Kurdistan Region. 


\section{Introduction:}

Iraqi Kurdistan Region would be important geographically for the U.S. foreign policy because it is close to American's enemies, such as the previous Iraqi regime the Saddam regime, and more recently the terrorist group known as the Islamic State (IS), as well as Iran and Russia. The U.S. may enhance its relations with the Iraqi Kurdistan Region in the Middle East because it has significant territory and good military forces for fulfilling the U.S. foreign policy aims in this area. Since the end Cold War period, the U.S. has used the Iraqi Kurds' territory and Kurdish forces to attack its enemy in the region. For example, the U.S. intervened in Iraq in the Gulf War One, via Operation Desert Storm, in 1990 to 1991. In addition, the Iraqi Kurds' land was instrumental in the U.S. intervention policy in Iraq in 2003. Furthermore, the U.S. has intervened against the Islamic State since 2014.

This paper argues that because it is crucial to know and understand the nature of the superpower strong relations with the non-state actor in the Middle East. Therefore, this study aims to critically examine the U.S. and Iraqi Kurdistan Region relations from a geopolitical perspective, which is the relationship between politics and economics geography, since 2003. Furthermore, by focusing on two main factors, namely the military relations between the U.S. and the Iraqi Kurdistan Region, and security and stability of the Iraqi Kurdistan Region, this research intends to answer the following significant question: dose geopolitical perspective influence on relations between the U.S. and the Iraqi Kurdistan Region? This article firstly focuses on two wars, namely the Iraq war in 2003 and the Islamic State war since 2014, and secondly focuses on security and stability in the Iraqi Kurdistan Region, to illustrate how Iraqi Kurds' land and Kurdish forces have positively affected American - Kurds relationship because of Iraqi Kurdistan's strategic position and useful military strength for achieving the policy aims of the U.S. interventions. In other word this paper will show how the cooperation with Kurds assisted the US in a manner that generally supported and legitimated the dominant U.S. geopolitical position of a particular event. 


\subsection{The Iraq war in 2003:}

The U.S. foreign policy towards its allies varies in accordance with its changing enemies and interests. For this reason the U.S. alliances in the Middle East may change from time to time. In his article, "The Persian Gulf Crisis and the "New" World Order', Layne stated that in May 4, 1990, President George Bush, at Oklahoma University, stated that "You see, our enemy today-if you think about it, what's the enemy today-our enemy is uncertainty and instability" (Layne, 1992, p: 13). For example, the U.S. foreign policy towards Turkey changed in the period from the end of the Cold War to the Iraq war in 2003. During this period, in the greater Middle East, the US-Turkey alliance changed from a 'strategic partnership' to a 'partnership for democracy'. Aylin Guney1 observed that in November 1999, during the visit of US President Clinton to Turkey the idea of 'strategic partnership' was first used (Guney, 2005, p: 346). Also, in his article, 'Turkey and the United States: The impact of the war in Iraq', Meltem Muftuler-Bac argued that in 1999, US and Turkey relations were defined as a 'strategic relationship' (Muftuler-Bac, 2005, p: 61).

However, the prime example of how US foreign policy has changed in the Middle East is the change in the U.S.-Turkey relations. During the Cold War period, Turkey had a strategic partnership whereby the U.S. used Turkish territory against the Soviet Union. Nonetheless, after the Cold War period, the U.S.-Turkey relations, particularly during the Iraq war, changed from a strategic partnership to a partnership for democracy because the U.S.' enemies and interests changed. According to Guney, when the threat posed by the Soviet Union to the U.S. had receded, U.S.-Turkey relations deteriorated, especially during the Iraq war in 2003. In addition, the Iraq war created a serious crisis of confidence for both the U.S. and Turkey (Guney, 2005, p: $347,353)$. Turkey was not only reluctant to take a part in the U.S. led war, but also closed its borders and air bases to coalition forces (Guney, 2005, p: 348). On 01 March 2003, the Turkish parliament refused to send Turkish soldiers abroad or to allow foreign troop deployment in Turkey (Guney, 2005, p: 350). It can be argued that U.S. foreign policy towards Turkey was changed by the Iraq war in 2003 and that Turkey is no longer a strategic partner to the U.S. 
Furthermore, at the beginning of 2004, Paul Wolfowitz, the U.S. Deputy Defense Secretary, (cited in Guney) pointed out that:

Our strategic partnership has changed. It is no longer as it was before. In the past, this relationship was based on a military basis. Only military relations used to be discussed. This era is now closed. Military relations, of course, do exist but the new strategic partnership is not based on a military field but rather on democracy and politics (Guney, 2005, p: 354).

In the light of Wolfowitz's argument, the U.S.' strategic partnerships are changing. Also, Guney noted that after the Cold War period, the U.S. military aid donations were reduced to low interest loans, for buying military equipment, and the overall level of military assistance to Turkey decreased (Guney, 2005, p: 344). A speech by Edward Derwinski, a former member of Congress, clearly stated the reason for the reduction in military aid: "We provide military assistance to countries only when there is a common military purpose" (Guney, 2005, p: 345). This shows that although Turkey's strategic military location was significant to U.S. foreign policy during the Cold War period, in the post $9 / 11$ period, especially due to the Iraq war, Turkey-U.S. relations have changed because the U.S. geopolitical military interests have changed. In 2003, the U.S. used cooperation with the Iraqi Kurdistan Region to intervene in Iraq. Since the Iraq war (2003), the US has focused on the Iraqi Kurdistan Region to enable it to fulfill its interests in the region.

The Iraqi Kurdistan Region played a significant role in preparations for the Iraq war in 2003. The Kurds and other opposition groups met in Kurdish territory to discuss the overthrow of Saddam's regime, as noted by Kenneth Katzman2. In February 2003, all the opposition groups met in Iraq Kurdistan Region to prepare for the aftermath of Saddam Hussein's regime (Katzman, 2010, p: 2). It appears that the U.S. worked with Kurds and other Iraqi opposition groups in the years before Bush's intervention. Also, this shows that Iraqi Kurdish geopolitics were important for the U.S. and all Iraq's opposition groups during the Iraq war, because the Iraqi Kurdish territory was the 
nearest point to Saddam's regime. Also, this was a place where all opposition groups could meet to discuss the U.S. war plan towards Iraq and the future of Iraq.

The Iraq war was a good opportunity for Iraqi Kurds to enhance their relations with the U.S. because of the significance of its territory for the U.S. intervention in Iraq in 2003. James E. Kapsis3 noted that the US Central Command General Tommy Franks and the US Secretary of Defense Donald Rumsfeld told US president Bush that the northern front was an essential part of their war tactics against Iraq (Kapsis, 2006, p: 35). It can be argued that Kapsis' interpretation seems to be correct because of the essential role the Iraqi Kurdistan Region played in the U.S. war plan and the overthrow of Saddam's regime in 2003.

In 2003, Iraqi Kurdish forces formed an effective alliance with the U.S. forces to eradicate the regime of Saddam Hussein in the north of the country, with the U.S. troops and Iraqi Kurdish soldiers cooperating against the Iraqi regime to occupy northern Iraq. As noted by Michael Codner in his article, 'The two towers, 2001-13', on 10 April 2003, they invaded the Kirkuk city and on 11 April 2003 moved to Mosul4 city (Codner, 2014, p: 60). This reflects the key role played by Iraqi Kurdish forces and its territory in destroying Saddam Hussein's regime in 2003.

Meanwhile, the U.S. may favour protecting Iraqi Kurds from threats by external forces if the U.S. and Iraqi Kurdistan Region share a mutual interest. The Iraq war (2003) is an example of the U.S. protects Iraqi Kurdistan Region from its enemy. According to Soner Cagaptay5, on July 4, 2003, the U.S. troops arrested Turkish special operation solders in Sulaymaniyah6 who were working to assassinate elected officials. Many Turks saw this episode as a clear signal that the U.S. preferred Iraqi Kurdistan Region over a North Atlantic Treaty Organization (NATO) ally (Cagaptay, 2004). It can be argued that the U.S. might protect the Iraqi Kurdistan Region from an external threat even if such a threat originated from a U.S. ally, as Cagaptay illustrates that. This reflects the strong relationship between the US-Iraqi Kurds and that they help each other based on mutual interests. 


\section{QALAAI ZANISTSCIENTIFIC JOURNAL \\ A Scientific Quarterly Refereed Journal Issued by Lebanese French University - Erbil, Kurdistan, Iraq \\ Vol. (6), No (2), Spring 2021 \\ ISSN 2518-6566 (Online) - ISSN 2518-6558 (Print)}

In addition, when the latest rockets attacked at Erbil International Airport by Iranian agent militia a few months ago, for example, on 15 February 2021, Saraya Awliya claimed responsibility for the attack, the U.S. has a good react to protect the Iraqi Kurdistan Region and this may enhance relations between the U.S. and IKR. According to the Reuters, in January 2020, an airstrike well-arranged by former president Donald Trump that killed Iran's top commander Qassem Soleimani, and sent the Iraqi Kurdistan Region to the brink of a full-scale conflict. After multiple rockets were thrown against Erbil International Airport and the U.S.-led coalition by the Iranian agent militias, the U.S. has sometimes answered with airstrikes against them in Erbil (Reuters, 2021). Taking Reuters argument into account, the U.S. may protect the Iraqi Kurdistan Region from any threat and enhance its relations with IKR.

\subsection{The Islamic State war since 2014:}

The U.S. war against the Islamic State differs from its previous interventions because Kurdish forces are fighting on the ground alongside U.S. forces in the air to defeat the Islamic State. In the past, the U.S. tended to fully intervene in countries, using troops, warships and air forces. Since the end of the Cold War, American military forces have been deployed in several countries. For example, from 1992 to 1994, the United State sent 27,000 soldiers to Somalia, as part of Operation Restore Hope; from 1994 to 1996, 20,000 US troops were engaged in Haiti to change the regime and restore President Jean Bertrand Aristide to authority; and America sent 20,000 troops as part of NATO's implementation force (IFOR) in 1995, with 7,000 troops remaining between 1996 to 1998 as part of the stabilization force (SFOR). Also, the United State led air strikes and patrolled the no-fly zone in Bosnia for three years. America sent 1,500 soldiers to Macedonia as part of a United Nations in contradiction of Serbia (Jentleson \& Britton, 1998, p: 395,396)7. However, a change in US foreign policy regarding intervention has occurred in the case of the Islamic State, in that the US has intervened without using ground troops.

Dale Sprusansky8 illustrates that Islamic State has a number of different names and acronyms. The Islamic State (IS) is the term used by the group itself. In many Western countries, the group is known as the Islamic State of Iraq and Syria or ISIS. The Islamic 
State of Iraq and Levant or ISIL has been used by the American government and some media. Other countries call the group the Islamic State of Iraq and al-Sham. In the Arabic world, the group is mentioned to as al-Dawla al-Islamiya fi Iraq wa al-Sham (Da'ish) (Sprusansky, 2014). This paper prefers using the Islamic State as a terrorist group among others because IS has controlled vast areas in Syria and Iraq. Also, it has terrorized and killed many Syrian, Iraqi, and Kurdish civilian people and it carried out genocide against Kurdish Yazidis, an ethnic and religious minority in the Kurdistan region. In addition, IS as a terrorist group is a global threat; IS even affects some states far more than others. The U.S. has been threatened by terrorism; this pushes America to fight against IS.

Iran, a neighbour of the Islamic State, is one of the key players in the Middle East. Nevertheless, the U.S. and Iran cannot cooperate together to fight against IS because they have deeply conflicting views on the matter. Although IS has been threatening both countries, American and Iranian officials pointed out that they could not cooperate to fight against IS. As Dina Esfandiary9 and Ariane Tabatabai10 stated, whilst IS is a big issue for both the US and Iran, the American Secretary of State opposed Iran being invited to the France international conference in September 2014. Also, Supreme Leader of Iran, Ayatollah Khamenei, claimed that Iran had refused requests by the US for collaboration (Esfandiary \& Tabatabai, 2015, p: 1). It is clear that despite the IS threat to both countries, the US and Iran could not collaborate on fighting against IS because of their hostile relationship.

Furthermore, although Turkey has a border with the Islamic State and is both a member of NATO and Washington's key ally in the region, it has been unwilling to take part in fight operations against IS. The U.S. has tried without success to convince Turkey to play a more active role in combating IS. Phillips noted that Turkey is a problematic country for Obama's campaign against IS, whilst its reluctance to respond to IS aggression has increased suspicion about Turkey's reliability as an ally. Although Turkey had permitted the United State warplanes to operate from Incirlik Air Force base and promised to establish a base to train the Syrian opposition, it did not fulfill its promises. Furthermore, there are strong rumours accusing Turkey of supporting IS 


\section{QALAAI ZANISTSCIENTIFIC JOURNAL \\ A Scientific Quarterly Refereed Journal Issued by Lebanese French University - Erbil, Kurdistan, Iraq \\ Vol. (6), No (2), Spring 2021 \\ ISSN 2518-6566 (Online) - ISSN 2518-6558 (Print)}

financially and logistically. Turkey also has transited Jihadis from Turkey to Syria (Phillips, 2014, p: 355). Moreover, Thomas L. Friedman11 (cited in Phillips, 2014) noted, "Erdogan stands for authoritarianism, press intimidation, crony capitalism, and quiet support for Islamists including ISIS" (Phillips, 2014, p: 355). Hence, it can be argued that although Turkey is a member of NATO and America key supporter in the region, it is reluctant to join the military campaign against IS. This may decrease Turkey's role in the region and adversely affect U.S.-Turkey relations.

However, the U.S. has since 2014 cooperated with Iraqi Kurdish forces on the Kurds' land to fight against the Islamic State. Kurdish forces, known as peshmerga, are on the ground and the U.S. forces are in the air, fighting together as allies against IS. Because Kurdish forces are fighting these barbaric terrorists in Iraq and Syria, the U.S. and its allies may not feel that it is necessary for them to send in ground troops. American President Barack Obama (cited in The White House, 2014) illustrated that American pilots have effectively destroyed Islamic State's weapons and equipment. Meanwhile, Kurdish troops on the ground battle against IS to defend their territory (The White House, 2014, p: 1). As a result, a new relationship has developed between the U.S. and Iraqi Kurdistan Region in the Middle East because of their cooperation in the fight against terrorism.

In addition, geopolitically, Iraqi Kurdish land is important for the U.S. administration in combatting the Islamic State. As Michael Knights12 and Sam Metz13 pointed out, "Iraqi Kurdistan's long frontier with ISIS and the safe domestic security environment make it an optimal air base location for U.S. drone and Special Forces operations against ISIS, whether covert or overt. The Kurds control an important portion of Iraq's border with Syria, providing useful access to opposition-held areas." (Knights \& Metz, 2014, p: 2). The quotation shows that the Iraqi Kurdistan Region can be significant geographically for the policy of U.S. intervention against the Islamic State because it has a long border with the Islamic State. For this reason, it appears that the U.S. needs the Iraqi Kurdistan's position to fulfill its intervention policy against the Islamic State. 
Moreover, after ISIS threatened millions of people in Iraq and Syria and killed numerous Kurds, the U.S. directly intervened against IS. When IS moved into Iraq, one Iraqi Kurdish victim said, "There is no one coming to help". President Barack Obama answered in a late night television broadcast on 07 August 2014, "Well, today America is coming to help". He added, "We can act carefully and responsibly to prevent a potential act of genocide". On 08 August 2014 two American warplanes bombed Islamic State fighters near Erbil (Mint, 2014 p: 1). This quick response to Kurdish requests on the part of the U.S. might imply a favorable attitude of U.S. foreign policy towards the Iraqi Kurdistan Region. In other words the U.S. could protect geography of the Kurdistan Region.

The U.S. has not always responded to such desperate situations in Iraq. For example, on 10 June 2014, while the Islamic State invaded Mosul, the U.S. did not intervene. However, after IS overrun Makhmour, a town just 30 kilometers in the south of Erbil, on 08 August 2014, the U.S. began to bomb IS at the same day (Phillips, 2014, p: 351, 353). Phillips argues that the U.S. intervenes in countries when its interests and alliances are in danger, whilst in other cases, such as Mosul, the U.S. has been reluctant to intervene. Also, as the evidence shows that relations between $\mathrm{KRI}$ and U.S. could be interpreted as a long-term strategic relationship.

Furthermore, the U.S. intervention policy against IS could be a way to defend Iraqi Kurdish self-rule in the Middle East. Borzon Daragahi's article 'US attempt to aid Kurds may backfire by helping Isis' reports President Barack Obama's statement that US air attacks against IS will help to protect the self-ruled Iraqi Kurdistan Region and Kurdish religious minorities, including Christians and Yazidis, threatened by IS (Daragahi, 2014). The U.S. intervention could therefore protect the Iraqi Kurdistan Region and its Kurdish religious minorities against IS.

Moreover, in his article 'Obama's message to ISIS: Stay out of Kurdistan, but the rest of northern Iraq is all yours', Max Fisher presented a similar argument regarding President Obama's authorization of bombing against IS. Although President Obama did not specifically use the expression "red line", Fisher argued that the US takes 
military action against IS if - and only if - IS threaten the Iraqi Kurdistan Region. Thus, this is the red line (Fisher, 2014). Obama (cited in Fisher, 2014) stated that "To stop the advance on [the Kurdish capital city] Erbil, I've directed our military to take targeted strikes against ISIL terrorist convoys should they move toward the city" (Fisher, 2014). Fisher said, so far, it seems that President Obama's message to IS is "Stay away from Iraqi Kurdistan, and the rest of northern Iraq is yours to keep" (Fisher, 2014).

According to Fisher, in June 2014, IS occupied northern Iraq. Although IS took Mosul and much of the largely Sunni north of Iraq, the US did not respond with military force against IS. However, once IS made its first real push into the Iraqi Kurdistan Region, invading some Kurdish towns and coming dangerously close to the Kurdish capital, the attitude of the US changed and it acted against IS (Fisher, 2014). Also, Fisher said,

Invading Iraq's Kurdish region, it turned out, was Obama's red line for ISIS. There are a few reasons why. The Kurdish region is far stabler, politically, than the rest of Iraq... The Kurdish region, which has been semi-autonomous since the United States invaded in 2003 and has grown more autonomous from Baghdad ever since, also happens to be a much more reliable US ally than is the central Iraqi government. It has a reasonably competent government and military, unlike the central Iraqi government, which is volatile, unstable... With the rest of Iraq in chaos, the Kurdish region is also America's last reliable base in the country, so if Erbil falls to ISIS then the US could effectively be out altogether (Fisher, 2014).

As Fisher, for example, argued, the Iraqi Kurdistan Region became President Obama's red line for IS. White House officials said, “... the emphasis on defending Erbil came through loud and clear: the US is clearly designing its intervention around protecting the Kurdish region;..." (Fisher, 2014). If IS stay on the correct side of the red line, the US will not take any military action against it. It appears that the US is drawing a red line around the Iraqi Kurdistan Region, whilst also telling everybody outside it that they are on their own (Fisher, 2014). Fisher's interpretation is feasible, but difficult to prove due to lack of evidence. However, in the light of Fisher's argument, it seems 
that the Iraqi Kurdistan Region is a red line for the US government and the US may therefore protect it from attack by foreign forces because there is a good relations between the U.S. and Kurdistan Region.

The U.S. has led an international campaign against IS, in which it has sought to enlist international allies. Also, it has persuaded some countries, Australia as an example, to give arms to Kurdish forces. In his article 'Australia agrees to deliver arms to the Kurds in Isis fight', Jamie Smyth stated that the US president Barack Obama has requested the international community to fight against IS (Smyth, 2014). Australia's Prime Minister Tony Abbott (cited in Smyth, 2014) stated that the U.S. asked Australia to send weapons to Iraqi Kurdish fighters to battle against IS. Abbott added, "Royal Australian Air Force C-130 Hercules and C-17 Globemaster aircraft will join the aircraft from other nations, including Canada, Italy, France, the United Kingdom and the United States to conduct this important task", and that "Australian aircraft will take part in airdrops to Kurdish forces of weapons and munitions..." (Smyth, 2014). Additionally, according to the U.S. Department of State, in the battle to stop the Islamic State, America led international coalition would fight alongside more than sixty countries, including the United Kingdom, Australia, France, Germany, Qatar and Saudi Arabia (U.S. Department of State, 2014). Hence, the U.S. has not only aided Iraqi Kurdistan Region directly, but has also enlisted international support to help the Kurds against IS.

\section{Security and stability:}

Iraqi Kurdistan Region is a relatively secure and stable place for its citizens and visitors if compared to other parts of Iraq. Nechirvan Barzani has confirmed that the Iraqi Kurdistan Region has a good security situation. It is the best example to the rest of Iraq of achieving stability and peace. The security forces have worked hard to ensure that terrorists cannot operate in the region (Barzani, 2008, p: 15, 17). Also, in his article, 'Kurdistan's People: Key Builders of a New Federation', General Jay Garner stated that Kurdistan Region is "the other Iraq" (Garner, 2008, p: 24). It can be argued that because Iraqi Kurdistan Region is a safe place, this will enhance its relations with 
the regional and international community, especially with the U.S., which needs a stable and secure base for its policy in Iraq and the region as a whole.

Furthermore, American companies may feel safer in the Kurdish Region than other parts of Iraq and be more willing to work and invest in the Kurdish Region than other parts. Bengio observed that Kurdistan Region is a 'safe haven' for the U.S. activities in the region, namely in Syria, Iran, as well as in the Arab part of Iraq. Also, Bengio stated that in the last two decades, whilst no U.S. troops have been killed or injured in the Kurdistan Region, more than 4,400 US soldiers have died in the Arab part of Iraq (Bengio, 2012). Taking Bengio's argument into account, Kurdistan Region is a safe place for American soldiers and American activities in the region.

In addition, although the U.S. withdrew its military forces from Iraq in 2011, the U.S. may want to retain its military forces as well as its diplomatic mission in the Kurdistan Region of Iraq to fulfil its foreign policy aims in the region and to protect the Kurdish Region. On 1 February 2010, Qubad Talabani, Deputy Prime Minister in the Kurdistan Regional Government, pointed out,

This past week's visit by Masoud Barzani, President of the Kurdistan Region of Iraq, to the United States underscored the special relationship that has developed between the Kurdistan Region of Iraq and the United States. In each meeting our American friends emphasized the long-standing relationship between the United States and the people of Iraqi Kurdistan. But more importantly, during the Oval office meeting, the United States' relationship with Iraqi Kurdistan was regarded to be of the highest priority to the Obama Administration. President Barzani came to the U.S. to have one question answered: Will a withdrawal of U.S. military forces from Iraq mean a withdrawal of U.S. commitment and engagement with Iraq and Kurdistan? During our meetings, we heard an emphatic 'No'. We were continuously told that the U.S. will remain engaged and help the political forces in Iraq overcome their differences (Talabani, 2010, p: 1). 
This quotation highlights the long-standing relationship between the U.S. and Iraqi Kurdistan Region and the enormous importance of the Kurdistan Region to the U.S. government.

Moreover, it indicates that the U.S. and KRG are in a security partnership. Since 2003, there has been excellent cooperation between the U.S. military forces and KRG military forces in what could potentially be an attempt to stabilise the whole of Iraq. According to Knights and Metz, this is because they have a security partnership that has lasted for more than a decade. This situation has necessitated an upgrade of the U.S.-Kurds alliance. The Counterterrorism Partnership Fund is a main new security cooperation program between the U.S. and KRG that could tap into 5 million dollars. Kurdistan Region of Iraq's good security and excellent airports make it suitable to deliver the U.S. military train-and-equip program for Kurdish and Iraqi security forces. The plan may even open the door to greater U.S.-KRG security cooperation. If Washington expects Kurdish military forces to help stabilise the whole of Iraq, Kurdish troops need military cooperation with the U.S. (Knights \& Metz, 2014). It might be argued that since 2003, the U.S. and KRG have been engaged in effective security cooperation that could help them in the fight against terrorism and creating a stable and secure KRG and Iraq.

Also, KRG has opened its borders to U.S. military forces, providing a secure base for U.S. troops and military equipment. Meanwhile, many Kurds are hopeful about U.S. activity in the region. They may think that the U.S. can decrease differences between Erbil and Baghdad and that the U.S. may protect Iraqi Kurdistan Region if Baghdad makes problems for it. Knights and Metz stated, "The Kurds have been very open about their willingness to host a long-term U.S. military presence in Kurdistan, and at various points, the U.S. military deployed prepositioned equipment sets (tanks and armored vehicles) in the KRG to reassure the Kurds that Washington would not let Baghdad military pressure Iraqi Kurdistan in the future" (Knights \& Metz, 2014, p: 2). The quotation confirms the KRG's agreement to long-term deployment of the U.S. military in its region and suggests that U.S. military forces will protect the Kurdistan Region in the future. 


\section{Conclusion:}

The above arguments have shown that in geopolitical, U.S. interests in Iraqi Kurdistan are represented by the Kurds' strategic position, their military resources, security and stability. Also, as this article has shown, U.S. foreign policy has changed over time towards its alliances. Nowadays, the U.S. has good relations with the Iraqi Kurdistan Region. In 2003, they cooperated to destroy the regime of Saddam Hussain because of their mutual interests. In addition, Iraqi opposition groups gathered in the Iraqi Kurdistan Region to prepare for the U.S. intervention in Iraq (2003). The war against IS has been another factor in the improvement of U.S.-Iraqi Kurdistan Region relations. In this war, the U.S. and Iraqi Kurdish forces have strongly cooperated against IS. Also, while the U.S. cannot cooperate with Iran because of deep political differences and Turkey is reluctant to take part in combat operations against IS, the U.S. has found an ally against IS in the Iraqi Kurdistan Region. In addition, despite IS invading Mosul in June 2014, the U.S. did not intervene against IS until 08 August in Erbil. The U.S. intervention against IS could be a method to protect the self-ruled Iraqi Kurdistan Region. Moreover, the U.S. has sought help from other countries in an international campaign to help Iraqi Kurdistan Region in the fight against IS.

The most obvious finding to emerge in terms of security and stability is that the Kurdistan Region of Iraq is a secure and stable area when compared to other parts of the country. The U.S. companies and military forces would be safer in the IKR than other parts of Iraq. The U.S. - KRG are in a security partnership. There has been an excellent collaboration between the U.S. and KRG military forces since 2003. This paper elaborates the U.S. has good security relations with the KRG. Also, Because Iraqi Kurdistan Region is a safe place, the U.S. may want to maintain the excellent cooperation between U.S. and Kurdish military forces.

The U.S. geopolitical policy is an aspect of the U.S. foreign policy that needs to be considered. By focusing on two main factors, American - Iraqi Kurdistan Region military relations, and security and stability of IKR, this paper has answered the following question: dose geopolitical perspective influence on relations between the U.S. and the Iraqi Kurdistan Region? Returning to the question, it appears that the 


\section{QALAAI ZANISTSCIENTIFIC JOURNAL \\ A Scientific Quarterly Refereed Journal Issued by Lebanese French University - Erbil, Kurdistan, Iraq \\ Vol. (6), No (2), Spring 2021 \\ ISSN 2518-6566 (Online) - ISSN 2518-6558 (Print)}

geopolitical perspective is an important factor in influencing the U.S.-Iraqi Kurdistan Region relations. Also, the results of this investigation show that the Kurdistan Region of Iraq could be significant geographically for U.S. foreign policy because it is close to America's enemies in the region, such as the previous Iraqi regime of Saddam Hussain and more recently the Islamic State, besides, security and stability of the Kurdistan Region. The findings of this paper suggest that the Iraqi Kurdistan Region and the U.S. should further enhance their geopolitical relations. From the geopolitical perspective, it is recommended that the U.S. should pay more attention to the geography of Iraqi Kurdistan Region because it offers a good location for the US to fulfill its foreign policy aims regarding its enemies and hostile powers in the Middle East.

\section{References:}

Barzani, N. (2008) 'The Kurdistan Region: Invest in the Future (His Excellency Prime Minister Nechirvan Barzani introduces the Kurdistan Region)' in O. P. KRG (eds.) 'The Kurdistan Region: Invest in the Future'. Washington, DC: Newsdesk Media Inc, pp: 14-18.

Bengio, O. (2012) 'Will the Kurds Get Their Way?'. Available at: file://C:/Users/sava/Desktop/Will\%20the\%20Kurds\%20Get\%20Their\%20Way \%20\%20The\%20American\%20Interest.html (Accessed: 08 October 2015).

Cagaptay, S. (2004) 'Where Goes the US-Turkish Relationship?', Middle East Forum Promoting American Interests, 11(6), PP. 43-52.

Codner, M. (2014) 'The Two Towers, 2001-13', in Johnson, A. (eds.) Wars In Peace British Military Operations since 1991. London: Royal United Services Institute for Defence and Security Studies (RUSI), pp. 49-87.

Daragahi, B. (2014), 'US attempt to aid Kurds may backfire by helping Isis', FT.com, [Online]. Available at:

http://search.proquest.com.ezproxy.brunel.ac.uk/docview/1560907258?pqorigsite=summon (Accessed: 10 August 2015).

Esfandiary, D. and Tabatabai, A. (2015) 'Iran's ISIS policy', International Affairs, 91(1), pp. 115.

Fisher, M. (2014) Vox 'Obama's message to ISIS: Stay out of Kurdistan, but the rest of northern Iraq is all yours' Available at: http://www.vox.com/2014/8/8/5982275/obamasimplicit-bargain-with-isis-for-iraq (Accessed: 26 August 2015).

Garner, G. J. (2008) 'Kurdistan's People: Key Builders of a new Federation' in O. P. KRG (eds.) 'The Kurdistan Region: Invest in the Future'. Washington, DC: Newsdesk Media Inc, pp, 22-24. 


\section{QALAAI ZANISTSCIENTIFIC JOURNAL \\ A Scientific Quarterly Refereed Journal Issued by Lebanese French University - Erbil, Kurdistan, Iraq \\ Vol. (6), No (2), Spring 2021 \\ ISSN 2518-6566 (Online) - ISSN 2518-6558 (Print)}

Guney, A. (2005) 'An Anatomy of the Transformation of the US-Turkish Alliance: From "Cold War" to "War on Iraq"', Turkish Studies, 6(3), pp. 341-359.

Jentleson, B. and Britton, R. (1998) 'Still Pretty Prudent: Post-Cold War American Public Opinion on the Use of Military Force', The Journal of Conflict Resolution, 42(4), pp. 395417.

Kapsis, J. (2006) 'The Failure of US-Turkish Pre-Iraq War Negotiations: An Overconfident United States, Political Mismanagement, and Conflicted Military', Middle East Review of International Affairs, 10(3), pp. 33-45.

Katzman, K. (2010) Kurd in post-Saddam Iraq. DIANE Publishing.

Knights, M. and Metz, S. (2014) 'Last Man Standing: U.S. Security Cooperation and Kurdistan's

Peshmerga'. 24 July 2014. Available at: http://www.washingtoninstitute.org/policyanalysis/view/last-man-standing-u.s.-security-cooperation-and-kurdistans-peshmerga

(Accessed: 25 July 2015).

Layne, C. (1992) 'The Persian Gulf Crisis and the "New" World Order' in Carpenter, T. (eds.)

'America Entangled: The Persian Gulf Crisis and Its Consequence'. Washington: Cato Institute, pp. 7-14.

Mint (2014) 'US warplanes strike Islamic State artillery in Iraq', HT Media Ltd, New Delhi, 09 August 2014.

Muftuler-Bac, M. (2005) 'Turkey and the United States: The Impact of the War in Iraq', International Journal, 61(1), pp. 61-81.

Phillips, D. (2014) 'ISIS Crisis', American Foreign Policy Interests, 36(6), pp. 351-360.

Smyth, J. (2014), 'Australia agrees to deliver arms to Kurds in Isis fight', Financial Times Ltd, London (UK), 01 September 2014, p.3.

Sprusansky, D. (2014) 'Understanding ISIS: frequently asked questions. (Special Report)', Washington Report on Middle East Affairs, 33(7), pp. 19.

Talabani, Q. (2010) 'A Region and a Superpower: A Special Relationship', Qubad's Blog, 1 February. Available at: http://qubadsblog.com/2010/02/a-region-and-a-superpowera-special-relationship-2/ (Accessed: 24 July 2015).

The White House (2014) 'Statement by the President on Iraq'. Retrieved from The White House Office of the Press Secretary. Available at: http://www.whitehouse.gov/thepress-office/2014/08/09/statement-president-iraq (Accessed: 20 July 2015).

U.S. Department of State (2014) 'Joint Statement Issued by Partners at the Counter-ISIL Coalition Ministerial Meeting'. Retrieved from U.S. Department of State (Office of the Spokesperson). Available at: http://www.state.gov/r/pa/prs/ps/2014/12/234627.htm (Accessed: 9 July 2015).

Reuters (2021) 'Explosives-laden drone targets U.S. forces at Iraq's Erbil airport'. Retrieved from Reuters. April 15, 2021. Available at: https://www.reuters.com/world/middleeast/rocket-hits-near-erbil-airport-northern-iraq-kurdish-security-officials-2021-0414/ (Accessed: 8 May 2021). 


\section{QALAAI ZANISTSCIENTIFIC JOURNAL}

A Scientific Quarterly Refereed Journal Issued by Lebanese French University - Erbil, Kurdistan, Iraq

Vol. (6), No (2), Spring 2021

ISSN 2518-6566 (Online) - ISSN 2518-6558 (Print)

\section{ديدكاى جيوّيوّلَّو تيكى له يهيوهندى نيّوان ئهمريكا و هلريّمى كوردستانى عيّراق له .0902003}

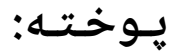

ئهم تويَرينهوه تيشك دهخاته سهر لايهنى جيوّيولهتيك له يهيوهندى نيّوان ئهمريكا و ههريّى

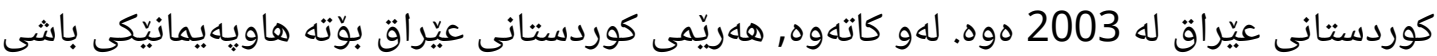
ئهمريكا لهبهرئهوهى جيوّيوّلهتيكى ههريّمهكه كرينكه بوّ سياسهتى دهرهوهى ئهمريكا. ههريّمى

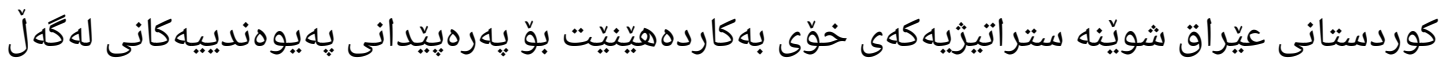

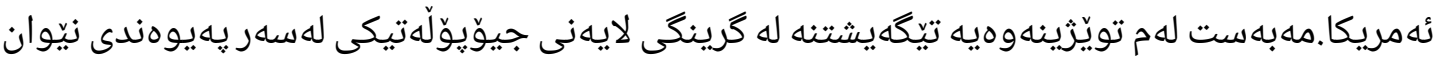
ئهمريكا و ههريّى كوردستانى عيّراق له 2003 هوه. ئهم تويّزينهوهيه دهروانيّته ئهم يهيوهندييه به تيشك خستنهسهر دوو فاكتهرى سهركىى: يهكهيان, يهيوهندى سهربازى له نيّوان ئهمريكا و ههريّمى كوردستانى عيّراق, كه شهرى عيّراق له 2003 وه شهرى داعش له 2014 هوه, دووهميان, ئاسايش و جيّيّيرى له ههريّمى كوردستانى عيّراق. ئامانجى ئهم تويّزينهوهيه وهلّام دانهوهى ئهم يرسياره

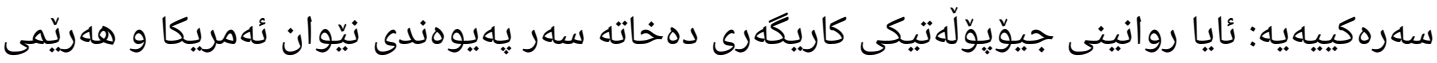

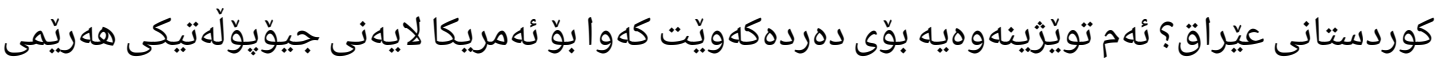

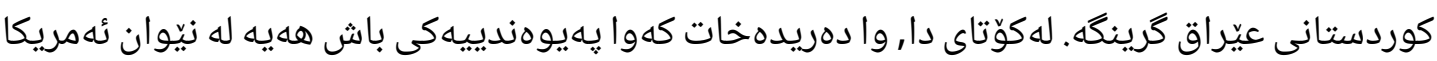

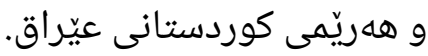

\section{المشهر الجيوسياسي، في العلاقة بين الولايات المتحدة الامريكية و اقليم كوردستان العراق منذ 2003.}

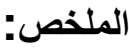

ان هذه المقالة تسلط الضوء على المشهد الجيوسياسي، في العلاقة بين الولايات المتحدة الامريكية و اقليم

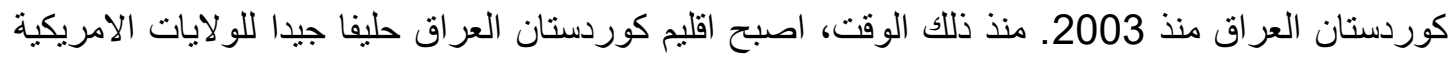




\section{QALAAI ZANISTSCIENTIFIC JOURNAL}

A Scientific Quarterly Refereed Journal Issued by Lebanese French University - Erbil, Kurdistan, Iraq

Vol. (6), No (2), Spring 2021

ISSN 2518-6566 (Online) - ISSN 2518-6558 (Print)

المتحدة كون موقعه الجغر افي ذات اهمية في نظر السياسة الخارجية للو لايات الامريكية المتحدة. لطالما استخدم الاقليم اهمية موقعه الاستر اتيجي لتقوية علاقاته مع الولايات الامريكية المتحدة. الغرض من هذه الدر اسة هو فهم

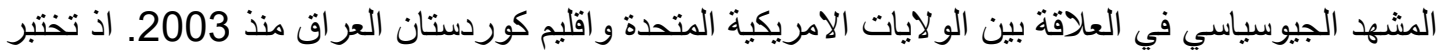
الوثيقة ذلك من خلال التطرق لعاملين حيويين وهما: اولا، العلاقات العسكرية بين الولايات الامريكية المتحدة

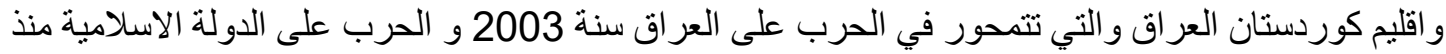
2014، وثانيا، امن و استقرار اقليم كوردستان العراق. يهدف هذا البحث الاجابة على السؤال الجوهري: هري: هل يؤثر المشهد الجيوسياسي على العلاقة بين الولايات المتحدة الامريكية واقليم كوردستان العراق؟ بستنتج البحث ان الموقع الجيوسياسي للاقليم ذا اهمية كبيرة بالنسبة للو لايات المتحدة الامريكية. في النهاية، يبدو ان العلاقة بين الو لايات الامريكية المتحدة واقليم كوردستان العراق جيدة. 